\title{
Rule of Law and Economic Growth
}

\author{
Jason Higbee and Frank A. Schmid
}

G ross domestic product per capita, adjusted for differences in purchasing power, varies widely among countries. In fact, a United Nations report shows that in 2001, real (that is, purchasing-power adjusted) GDP per capita ranged between a high of 53,780 (Luxembourg) and a low of 470 (Sierra Leone), as measured in U.S. dollars. ${ }^{1}$ What explains these crosscountry differences in real GDP per capita? Why are some countries wealthier than others?

Admittedly, there are large differences in countries' endowments with natural resources; however, an abundance of natural resources (or lack thereof) cannot fully explain the state of a country's economic development. Japan, for instance, has few natural resources. Yet, it is one of the richest countries in the world. A country's ability to accumulate physical and human capital, and the efficiency with which it turns its capital and natural resources into goods and services, seems to be a key factor. But what explains these cross-country differences in economic activity?

In an influential article, La Porta et al. ${ }^{2}$ argue that countries adhering to common law generally have the strongest legal protection for investors, followed by countries adhering to civil law adopted from the German and Scandinavian legal traditions; countries rooted in French civil law offer the weakest legal protection. A notable difference between these two legal systems is that common law, which is of English origin, gives priority to jurisprudence over codified doctrine, while the opposite holds for civil law, which originates from ancient Rome. Legal systems that provide strong legal protection for investors have permitted the development of sophisticated financial markets, which enhances the economy's ability to bear risk. This ability to spread risk over a multitude of investors is critical for entrepreneurship and economic growth.

But differences in the legal system are only part of the story. Actual enforcement of the law is also important. Corruption renders codified law ineffective. By weakening property rights, corruption deprives investors of compensation for risk taking and increases uncertainty about potential investment payoffs. This decreases the incentive to invest, which in turn dampens economic growth.

There are also unwritten rules that allow economic agents to trust one another. Trust is critical where matters are too complex to be written into law or where enforcing these laws is too costly. In fact, many contracts in the business world are implicit (and, hence, not enforceable) rather than explicit. Yet, the contracting parties abide by these implied agreements because reputation is valuable. In a recent speech about corporate governance and financial market malfeasance, Federal Reserve Chairman Alan Greenspan argued that trust and reputation were so valuable to 19 th century bankers and companies that the penalties for breaking this trust were severe enough to make economic commerce, to a large extent, self-regulating. ${ }^{3}$

The chart shows that countries with less corruption (that is, a higher value on the corruption perception index) tend to have higher levels of GDP per capita. The correlation between the two variables is 0.87 , which is statistically significant. Of course, while correlation is not evidence of causation, there is little doubt that corruption depresses economic activity.

\footnotetext{
${ }^{1}$ United Nations Human Development Report 2003, http://hdr.undp.org/ reports/global/2003.

${ }^{2}$ La Porta, Rafael; Lopez-de-Silanes, Florencio; Shleifer, Andrei; Vishny, Robert W. "Law and Finance." Journal of Political Economy, December 1988, 106(6), pp. 1113-55.

${ }^{3}$ Alan Greenspan (2004) "Capitalizing Reputation," http://www.federalreserve.gov/boarddocs/speeches/2004/20040416/default.htm.
}

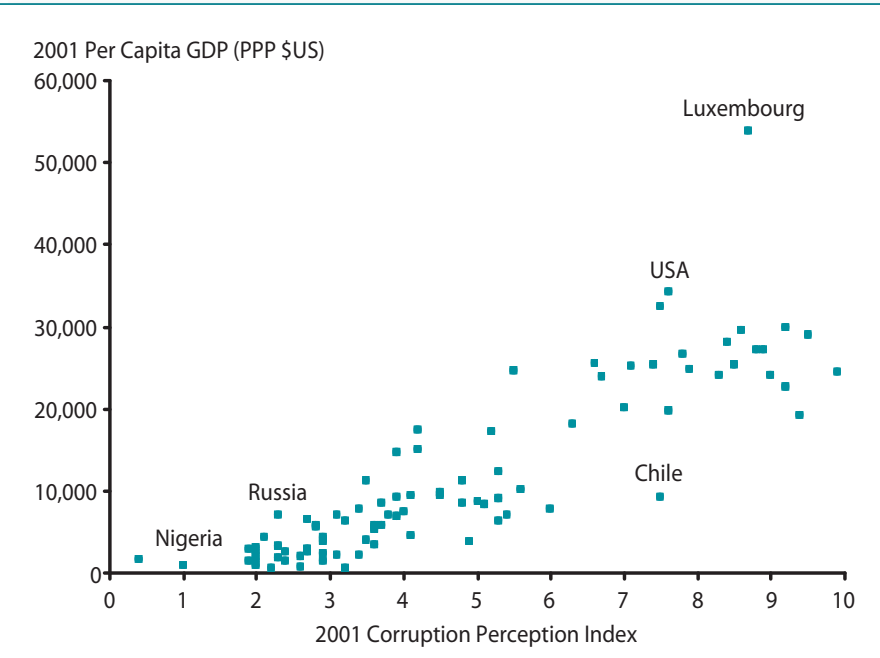

SOURCES: United Nations Human Development Report 2003 http://hdr.undp.org/reports/global/2003. Global Corruption Report 2001, http://www.globalcorruptionreport.org. 